\title{
Synthetic and Analytical Accounting of Inventory as a Tool to Improve Inventory Accounting System in Vietnam
}

\author{
N. K. Rozhkova
}

\begin{abstract}
There are no doubts about changes which have occurred in Vietnamese accounting regulations and practices since the mid-1980s, targeted to economic liberalization and development closer links with Western economies. The current accounting system represents a mixture of some basic features retained from Soviet Union and French-influenced system and new elements taken from Western accounting. This paper discusses an inventory accounting in Vietnam, names current problems and proposes some solutions and prospective developments in order to contribute to the harmonization of accounting standards in Vietnam.
\end{abstract}

Index Terms-Analytical accounting, inventory accounting, synthetic accounting.

\section{INTRODUCTION}

In a competitive environment, enterprises, in order to meet variety of consumers' needs, should develop trade relations, thereby increasing production and consumption. To achieve high performance, managers apply different control mechanisms in a company as the different ways for business and employee management, including an accounting.

The information contained in accounting, as a source of information is very important for managers and other users to reduce uncertainty about the financial position and performance of the company and to make decisions relating to the business [1]. Thus, the success or bankruptcy of the enterprise is based largely on accounting and its reliability and authenticity.

Accounting of inventory is an essential element for complete, accurate, precise understanding of the company's property in certain period of time. Users of the information about the availability and safety of inventories are mainly employees and third-party organizations, especially buyers. Inventory accounting helps to make better managerial decisions on the purchase of goods, their range and conquest of markets, both in Vietnam and in the world.

At the same time, globalization and regionalization is one of the main trends in the development of modern economic relations [2]. In order to win markets, Vietnam have to continuously pursue an economic integration, for example apply the best methods of inventory accounting, which are used in developed countries.

Vietnam is obliged to create stability in the economic environment and financial performance, as well as to continue improving the inventory accounting to realize progressive changes in order to approaching the principles

Manuscript received November 14, 2013; revised January 3, 2014.

N. K. Rozhkova is with the Accounting and Auditing, State University of Management, Moscow, Russia (e-mail: nakoro@mail.ru). common in the world, creating a common language of accounting and improving the ability to compare and evaluate the economic benefits.

In response to major changes in its socioeconomic environment, the procedure of organizing the accounting in Vietnam, adopted in 1995, has used some accounting principles and standards of International Federation of accountants (IFAC) and was built on the basis of the application of accounting from developed countries. However, it was only a first step towards the application of international principles and standards, while the mechanism of financial and management accounting, accounting legislation do not sufficiently match the level of developed countries.

This is especially true for inventory accounting, since the current stage of accounting in certain positions is significantly different from those generally accepted in international practice. In addition, by analysing the inventory accounting in Vietnam, we have revealed many problems that require immediate solutions because inventory are a significant share of the property of Vietnamese' companies.

For many years the accounting in Vietnam was under the influence of antiquated principles. The period of reformation was started in 1986, but the analysis of the reforms defected that the legislation of the accounting still needs serious improvements [3].

In addition, although the Vietnamese accounting standards have been constructed on the basis of international standards, there are significant differences on certain points. In order to improve the Vietnamese accounting standards and to converge them with international ones as the International Accounting Standards Board (IASB) formally proposed [4], it is necessary to develop and perfect the accounting system as a whole and inventory accounting in particular. Fig. 1 presents different ways of inventory accounting improvement in Vietnam.

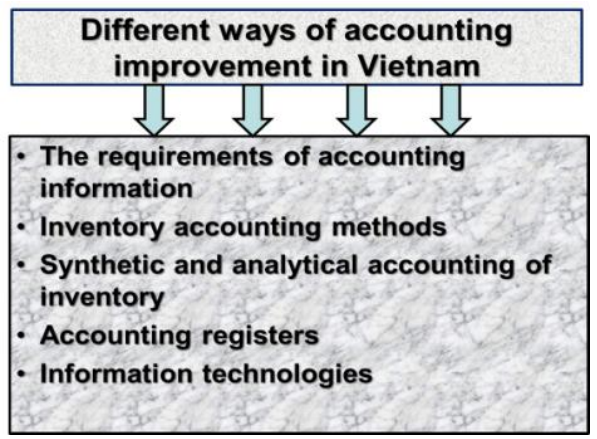

Fig. 1. Different ways of inventory accounting improvement in Vietnam.

This paper discusses synthetic and analytical accounting of inventory as a tool to improve accounting system in Vietnam. 
This study represents a next step in addressing the issues of accounting standards improving or implementing a "convergence" concept, by showing the problems in Vietnamese's inventory accounting if compare with international ones, and proposing their possible solutions.

\section{SynthetiC AND ANALYTICAL ACCOUNTING OF MERCHANDISE INVENTORY}

\section{A. Accounts: "The Initial Inventory Price" and "Costs of Inventory Purchasing”}

The accounting system of Vietnam currently defines the content, description of the accounting associated with the process of inventory accounting. Legislation of inventory accounting basically meets the requirements of management. Analysis of the system of inventory accounting showed a selective application of models, standards, rules and practices of international accounting in Vietnam [3]. However, along with the advantages there are some problems that need resolutions.

By investigating Enterprise Accounting System (EAS, 2006) of Vietnam, we have found the first problem-the existence of two duplicating accounts used for recording the initial inventory price and costs of inventory purchasing. This duplication can not only intricate the accounting in organizations but also complicate activities of monitoring and control by the fiscal authorities.

One of the requirements of building a system of accounting is to satisfy accounting users' needs of reliable information, to increase the ability to make effective management decisions, as well as to make an easy and convenient synthetic and analytical accounting. The accounts must be in the amount and quality to ensure the practicality and usefulness of the information for business management. However, there are two identical accounts for inventory in Vietnam, making accounting system more cumbersome and complex.

Notice that in Vietnam, the two methods of inventory are used: the periodic inventory method and the perpetual inventory method. The titles of the methods are descriptive. Under the periodic method we periodically define the amount of goods resting in inventory where periodic is established once every accounting period and usually at the end of the accounting period [5].

According to EAS while the perpetual inventory method, the organization should record the initial inventory price and costs of inventory purchasing in the account 156 "Inventory", which is detailed on sub-accounts:

- 1561-“The initial inventory price".

- 1562-“Costs of inventory purchasing”.

Organizations which use the periodic inventory method, should record the initial inventory price and costs of inventory purchasing in the account 611 .

At the end of each month, the organization is obliged to determine the amount of expenditures on the purchase of goods which has been sold during the period. However, companies that apply the method of perpetual inventory can account costs of inventory purchasing in the cost of sold goods and goods in stock. There is a contradiction - the use of two accounts for the same category of actions.

Moreover, in the method of periodic inventory, account 611 is only used to reflect the movement of goods at the beginning and end of the reporting period and has no residue. Thus the account 611 has no balance and characterizes the movement of goods at the beginning and end of the period. On the debit side there is a beginning of the period, on the credit side - the end of the period. This position is somewhat distorts the economic understanding of the account as violating the principle of active account: the debit - receipt of goods and the credit - its disposal.

Thus, this duplication of accounts represents a complex and controversial accounting process that create difficulties for making a company's competent and accurate accounting policies and for control from the part of state.

To conclude, we think that it is necessary to abolish the account 611 and to keep the account 156 for both inventory methods in order to simplify and clarify the inventory accounting of Vietnam.

\section{B. Analytical Accounts and Inventory Accounting Methods}

The companies in Vietnam buy and sell diverse assortment of products, product types, and different units of accounting. And as have been mentioned above only two inventory methods are used. We can name the second problem — lack of applying international experience, particularly about analytical accounts used in developed countries.

Thus, in the United States' accounting, companies use the modified perpetual inventory system for the accounting of inventory. Under the modified perpetual system, records are kept of increases and decreases in quantities of inventory but not the costs of these units. Thus, efficiency of change control of stocks increases, which is realized continuously and company knows the quantity of goods on hand and when to reorder.

French accounting allows using periodic inventory method and in order to monitor continuously the fluctuations of stocks, reflect these fluctuations in special registers using the perpetual inventory method. Accordingly, the French accounting combines two methods into one.

Even if the current accounting system in Vietnam combines basics taken from the western accounting and some elements retained from the pre-1995 accounting system, there remain significant differences between Vietnamese Accounting Standards and international ones [6]. As part of the process to integrate Vietnam more closely into global economies, the suggestion to use different inventory methods is made.

Moreover, in order to improve the analytical accounting of inventory and avoid errors in accounting, as well as to increase using information technologies and international experience, we recommend opening analytical accounts of several levels for the account 156 "Inventory".

- 1 level-reflecting the total cost of company's inventory (merchandise, raw materials, and finished and unfinished products which have not been yet sold).

For example: account 156 - Inventory.

- 2 level-reflecting the initial inventory price.

For example: account 1561 - The initial inventory price.

- 3 level-reflecting the initial inventory price for each 
group of products.

For example: account 1561.1 - the initial inventory price of household tools, account 1561.2 - the initial inventory price of electronic tools

- 4 level-reflecting the initial inventory price for each group of products for each shop, store etc.

For example: account 1561.1.1 — the initial inventory price of household tools for store number 1, account 1561.1.2 - the initial inventory price of household tools for store number 2 .

- 5 level-reflecting the initial inventory price for each group of products for each shop, store etc. for concrete unit of product.

For example: account 1561.1.1.01 — the initial inventory price of household tools for store number 1 screwdriver, account 1561.1.1.02 — the initial inventory price of household tools for store number 2 pliers.

To sum up, opening analytical accounts of several levels for the account 156 "Inventory" and using different inventory methods will improve company's decision making, will help to achieve a detailed view into inventory transactions, enable deep analysis and increase of reporting thoroughness and will assume measures toward harmonizing the national accounting system with international systems.

\section{Allocation Costs of Sales}

In accounting system of Vietnam, there is another problem - the allocation cost of goods sold in two components: the costs of sales (goods that are sold) and costs of sales goods remained. Under current legislation the allocation of costs is allowed only for organizations with a long production cycle. And duration of the production cycle is not defined in the legislation, so organizations themselves set the duration and tend to completely write off the costs of sale during the period, not including administrative costs and not having costs for the remained goods.

There is a contradiction: the duration of the production cycle and the allocation of costs. It seems that the length of the production cycle affects the level of costs indirectly. From the management point of view, costs should be grouped according to their cost center, and allocation of costs should be justified in critical accounting policy.

In Vietnam, the costs of sales goods are grouped into two items: the cost of storing and directly costs of sales goods (Fig. 2).

The costs of storing products in some companies take a significant share of the costs of sales and form part of cost products in stock at the end of period.

We think that the cost of storing should account monthly, using the account experience of Russia [7]. This mechanism will provide a reasonable estimate of the cost of inventory for each month. In calculating the average percentage we suggest using the following formula:

$$
C \%=\frac{(I b+C)}{(\text { Ie }+ \text { Inew })}
$$

where

$I b$ - inventory in the beginning of period.
$C$ - cost of storing during the period.

$I e-$ inventory in the end of period.

Inew - inventory arrived during the period.

The costs during the period are defined as a multiplication of the released inventory from the warehouse to the average percentage $(\mathrm{C} \%)$.

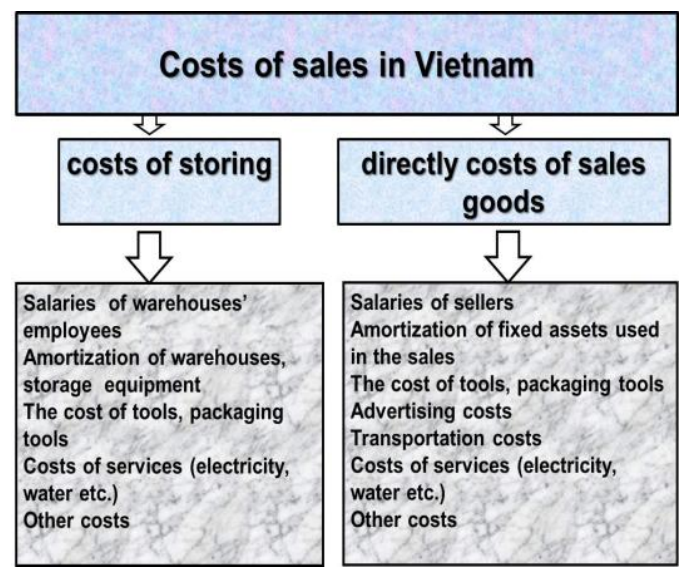

Fig. 2. The costs of sales goods in Vietnam.

We think that directly costs of sales goods can be divided into fixed and variable parts. In the variable part salaries of sellers can be included (if the salary is directly linked to turnover) and transportation costs).

It should be noted that the above measures will systematize and clarify the allocation costs of sales, increasing the precision and accuracy of accounting.

\section{CONCLUSION}

According to some researchers the international convergence of accounting standards is a phenomenon that began 30 years ago and is recognised by theorist and practitioners [8], [9].

In Vietnam, there is a centralized method of economy management, so the regulation of accounting has directive specificity. Although currently in Vietnam the existence of a mixed economy and the need to move the economy from planned economy to market one is recognized, accounting is still rebuilding very slowly and differs significantly from the international standards [6], [11].

This is especially true for inventory accounting, since at the current stage of accounting in certain positions it is different from generally accepted in international practice. In addition, in the organization of inventory accounting in Vietnam there are some challenges that claim immediate solutions because the inventory takes a considerable part of the property of Vietnamese' companies. The scientific novelty of the paper is to address a number of important theoretical and practical problems associated with the formation of the inventory accounting system in Vietnam and resolving some challenges in it.

\section{ACKNOWLEDGMENT}

The author would like to thank Rozhkova D. for her valuable suggestions. 


\section{REFERENCES}

[1] A. R. Belkaoui, Accounting Theory, Cengage Learning EMEA, 2004, ch. 2, pp. 37-76.

[2] J. Birkinshaw, A. Morrison, and J. Hulland, "Structural and competitive determinants of a global integration strategy," Strategic Management Journal, vol. 16, no. 8, pp. 637-655, 1995.

[3] A. Nguyen and G. Gong, "Vietnamese accounting reform and international convergence of Vietnamese accounting standards," International Journal of Business and Management, vol. 7, no. 10, pp. 26, 2012

[4] International Financial Reporting Standards. [Online]. Available: http://www.ifrs.org

[5] C. S. Warren, Financial and Managerial Accounting, South Western Educational Publishing, 2013.

[6] D. N. P. Anh and D. T. Nguyen, "Accounting in a developing transitional economy: the case of Vietnam," Asian Review of Accounting, vol. 21, no. 1, pp. 74-95, 2013.

[7] N. Decree. (28 Dec. 2001). On approval guidelines of inventory accounting. Ministry of finance, Russian Federation. [Online]. Available: http://www.kadrovik.ru/docs/pr.minfina.ot.28.12.01.n.119n.htm

[8] B. Moussa, "On the international convergence of accounting standards," International Journal of Business and Management, vol. 5, pp. 89-92, April, 2010.

[9] T. Chu. (2004). Accounting changes in a transition economy: The case of Vietnam. [Online]. Available: http://ro.uow.edu.au/theses/1903/

[10] F. B. Narayan and T. Godden. (2000). Financial Management and Governance Issues in Vietnam. [Online]. Available:
http://www.adb.org/Documents/Books/Financial_Mgt/Vietnam/preli ms.pdf

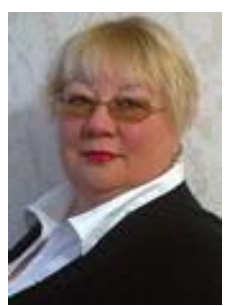

Rozhkova Nadezhda Konstantinovna was born in the Far East of Russia in 1948. She has finished a Khabarovsk Polytechnic Institute in 1971 and received $\mathrm{PhD}$ from Financial University under the Government of Russian Federation in 2006. Her research focuses on accounting and audit. She has a special interest in study of developing and forming of financial accounting in emerging countries. She has 37 years of scientific and pedagogical experience, including 6 years with the Accounting and Auditing Department in State University of Management, Moscow, Russia. Moreover, during 7 years she is a visiting professor in Financial University under the Government of Russian Federation. N. K. Rozhkova is actively involved in research work, her research results are relevant and novel, and possess practical and scientific value. In general, the results of her research activities are published in 98 scientific works. N. K. Rozhkova is a professional auditor, a representative of enterprise "Dalregioaudit" in Moscow, conducting the numerous auditing checks in various companies. Annually, she renovates her certificate of professional auditor. N. K. Rozhkova conducts research with students and helps with participating in the student conferences. Under her supervision students take part in the International Scientific Studen Conference in Moscow (Russia) and other academic activities, repeatedly winning prizes. 